\title{
MikroRNA'lar ve Atlarda MikroRNA'lar ile İlgili Yapılan Çalışmalar
}

\author{
Seda Ekici', Özge Özmen² \\ ${ }^{1}$ Veteriner Kontrol Merkez Araştırma Enstitüsü, Gıda Kontrol Laboratuarı, Ankara \\ ${ }^{2}$ Ankara Üniversitesi Veteriner Fakültesi, Genetik AD, Ankara
}

Geliş Tarihi / Received: 03.09.2015, Kabul Tarihi / Accepted: 10.02.2016

\begin{abstract}
Özet: MikroRNA'lar (miRNA)18-25 nükleotit (nt) uzunluğunda genom üzerinde protein kodlayan intron veya ekzon bölgelerindeki RNA genlerinden transkripsiyonu sağlanan, fakat proteine translasyonu gerçekleşmeyen, fonksiyonel RNA molekülleridir. Tüm canlılarda çeşitli fiziksel ve patolojik kondisyonlarda post-transkripsiyonel gen düzenleyici olarak miRNA'ların rolü evcil hayvanlar da dahil birçok organizmanın incelenmesiyle aydınlanmaktadır. miRNA'ların gen ekspresyonunda, fenotipik değişkenliğin şekillenmesinde ve hastalık gelişminde regülatör olarak önemli rollerinin olduğu tespit edilmiştir. Yapılan çalışmaların 1şığı altında miRNA'ların önemi son zamanlarda Veteriner Hekimlikte de fark edilmiştir. Taşıma ve eğlence için kullanılan, aynı zamanda ekonomik değere sahip evcil at (Equus caballus), insan uygarlığının çok önemli bir parçası olmuştur. Tıbbi açıdan at ile insan arasında alerji ve osteoartrit gibi 90'dan fazla kalıtsal hastalık ortaktır. Biyomekanik ve egzersiz fizyolojisi çalışmalarında en iyi model organizma attır. İnsanlık tarihi için at bu kadar önemli bir organizma olmasına rağmen, atlarda miRNA'lar ve miRNA'ların klinik kondüsyonlar üzerine etkisi hakkındaki çalışmalar oldukça azdır. Bu derleme miRNA'lar ve atlarda miRNA'lar ile ilgili yapılan çalışmalar hakkında bilgi vermek amacıyla hazırlanmıştır.
\end{abstract}

Anahtar kelimeler: Equus caballus, mikroRNA, mRNA

\section{MicroRNA's and Studies Performed on Horses Concerning MicroRNA's}

\begin{abstract}
MicroRNA's (miRNAs) are the functional RNA molecules consisting of about 18- 25 nucleotides (nt), transcribed but not translated to proteins through genes those are at the protein coding introns or exons on the genom. The role of miRNAs as a post-transcriptional regulator in all organisms on various physical and pathological conditions as enlightening through examining the organisms including domestic animals. miRNA's have been found to play critical roles on gene expression, occurance of phenotypic variations and as regulators on disease development. In scope of the studies performed recently, the importance of miRNA's were realized on Veterinary Medicine Equus caballus (domestic horse) has been a very important part of the human civilization since it is used for transportation and fun in addition to its economic value. Medically, over 90 hereditary diseases such as allergies and osteoarthritis are common between horse and human. The best model organism for studying biomechanics and exercise physiology are the horses. In spite of being such and important organism for the human history, studies related to miRNA's at horses on effect of miRNA's on clinical conditions of horses are very few. This review is prepeared in order to give information about miRNA's and limited in horses miRNA studies performed on horses
\end{abstract}

Key words: Equus caballus, mikroRNA, mRNA

\section{Giriş}

Memeli genomunun sadece \%3' lük kısmı protein kodlayan mRNA'ları ifade etmektedir. Geri kalan \% 97' lik kısım ise uzun ve kısa protein kodlamayan RNA' lardan oluşmaktadır [6]. Proteine çevrilemeyen RNA'lara kodlamayan RNA (ncRNA) ad1 verilmektedir [3,10]. Evrimsel açıdan korunmuş dizilere sahip ncRNA'lar biyolojik reaksiyonların katalizlenmesinden, hücresel savunmaya, gelişimsel süreçlerden hücresel cevaba kadar pek çok göreve sahiptirler [26]. ncRNA'ların diğer işlevleri arasında transkripsiyonel ve post transkripsiyonel gen susturumu ve kromozomlarin yeniden modellenmesi de yer almaktadır. Çok sayıda tipi bulunan ncRNA'lar, yaşam için gerekli ve düzenleyici ncRNA'lar olarak iki ana sınıfa ayrılmaktadır. Yaşam için gerekli ncRNA'lar canlıların bütün dokularında bulunarak çok sayıda işlevleri yerine getirirken, gen ifadesinin düzenlenmesinde işlevleri olan düzenleyici ncRNA'lar ise nt sayılarına göre uzun ncRNA (>200 nt) ve kisa ncRNA (<200 nt) olarak iki alt sinifa ayrilmaktadır [21]. X kromozomunun inaktivasyonundan sorumlu Xist ve Tsix RNA, embriyonik pluripotent hücrelerinin üreme hücrelerine 
farklılaşmasında ve transkripsiyonunda işlev gören Long intergenic non-coding RNA (LincRNA) ve mRNA'nın post transkripsiyonel düzenleyicisi olan circular RNA (circRNA)'lar uzun ncRNA sinifina, mRNA'nın transkripsiyonel düzenleyicisi olarak işlev yapan short interfering RNA (siRNA), mikroRNA (miRNA) ve eşey hücrelerinde transpozon ve retroelementlerin baskılanmasindan sorumlu olan P-element induced wimpy testis RNA (piwiRNA)'lar ise kısa ncRNA sinıfına girmektedirler [21,39].

\section{miRNA'ların Genomik Organizasyonu}

miRNA'ların kromozomal yerleşimleri kendilerinin anlatımını ve işlevlerini etkilemektedir. Bu nedenle miRNA genomik organizasyonunun bilinmesi önemlidir [27]. miRNAların yaklaşık yarısı küme yerleşimi gösterir. Küme şeklinde olan miRNA'lar operon benzeri bir yapıya sahip olup, polisistronik (Birden fazla proteinin genetik koduna sahip) olarak transkripsiyona uğrar [33,34]. Kümelenmiş miRNA'ların önemli bir özelliği de türler arasında korunmuş olması, homolog miRNA'ların tüm türlerde gözlenmesidir [28]. miRNA'lar genler aras1/ gen içi ve intronik/ekzonik yerleşime göre gruplandirılmaktadır $[14,40]$.

\section{miRNA Biyogenezi}

miRNA'lar işlevlerini çoğunlukla mRNA'nın 3' tercüme edilmeyen bölgesine ( 3 ' UTR) bağlanarak, daha azınlıkta 5'-UTR, ORF (open reading frame) ya da promotör bölgelerine bağlanarak yapmaktadirlar [13,31,32]. DNA'dan ilk olarak çoğunlukla RNA polimeraz II veya azınlıkta RNA polimeraz III enzimleri tarafindan $>1000$ nt uzunluğunda olgun miRNA'nın öncül transkripti olan birincil-miRNA (pri-miRNA) sentezlenir [8,34]. Karakteristik mRNA gibi pri-miRNA'ların 5' ucunda 7 metilguanozin başlığı ve 3' ucunda poli A kuyruğu bulunmaktadır $[36,38,42]$. Tek zincirden oluşan pri-miRNA'lar kendi üzerinde kıvrılarak saç tokası yapısını oluştururlar. Çekirdek RNAaz III endonükleaz ailesinden olan Drosha enzimi, alt ünitesi ile birleşerek pri-miRNA'yı keser ve kesilen miRNA'lar 70-100 nt uzunluğunda olup öncü miRNA'ya (pre-miRNA) dönüşürler [13,19]. pre-miRNA nüklear transport reseptör (Exportin 5) ile çekirdekten sitoplazmaya geçerek sitoplazmada RNAaz III ailesinden Dicer enzimi, alt ünitesi ile birleşir ve pri-miRNA'nın saç tokas1 yapısını keser. Dicer enzimi tarafindan kesilen RNA'lar 3' uçlarında 2 nt'lik çıkıntı kalacak biçimde 18-25 nt uzunluğunda kısa çift iplikli olgun miRNA'lara dönüşürler [14]. Çift iplikli miRNA'ların bir ipliği Argonuate-2 (Ago-2) bağlı RISC enzim kompleksine bağlanarak hedef mRNA'nın 3'UTR, 5'UTR, ORF bölgelerine ya da promotör bölgelerine bağlanarak ya da mRNA'yı parçalayarak translasyonu engeller [21,23]. miRNA'ların tipik yolaklarının dışında atipik yolaklar da tanımlanmış ve bu yolakların ortaya çıkış nedeni henüz belirlenememiştir. Bu yolaklar Drosha- bağımsız yolaklar ve Dicer bağımsız yolaklar olmak üzere ikiye ayrılırlar $[15,22,30,43]$. Atipik miRNA yolaklarını seçen bu RNA'lar kırpılma yapmaksızın henüz belirlenemeyen bir mekanizma ile kısa pre-miRNA benzeri saç tokas1 yapısı oluştururlar ve doğrudan Dicer enzimi ile kesime uğramaktadırlar. Ayrıca tRNA benzeri yapılar, pre-tRNA ve endo-siRNA yapıları da Drosha enzimine gerek duymadan olgun miRNA'y1 oluşturmaktadırlar [13,18,20,24].

\section{Atlarda Belirlenen miRNA'lar}

miRNA'ların gen ekspresyonunda, fenotipik değişkenlik şekillenmesinde ve hastalık gelişmesinde regülatör olarak önemli rollerinin olduğu tespit edilmiştir [7,9,11]. Atlarda miRNA'lar ile ilgili ilk çalışma Zhou ve ark. (2009) tarafından yapılmıştır. Bu çalışmada; 354 olgun at miRNA'ları belirlemek ve tanımlamak için in silico (RNA veri tabanları) analitik yöntem kullanılmıştır. At sperminde 82 adet yeni miRNA'nın varlığ 1 tespit edilmiştir ve sperm fonksiyonları, fertilite ve üremenin düzenlenmesinde miRNA'ların rolünün olduğu düşünülmüştür $[44,45]$.

Barrrey ve ark. (2010) tarafindan direkt klonlama teknolojisi kullanılarak sağlıklı ve miyopatik atlarda kas dokusunda miRNA'ların ifade profili belirlenmiştir [5]. Kalıtsal kas hastalığg olan atların kan örneklerinde kas-spesifik miRNA'ların varlığını tespit edilmiş ve atlarda kas patoloji tanısı için minimal invazif metodoloji ile yeni miRNA'ların geliştirilmesine olanak sağlanmıştır $[5,9]$.

Kim ve ark. (2014) Yeni Nesil Sekans (YNS) teknolojisi kullanarak iskelet kasları, kolon ve karaciğer dâhil normal at dokularından elde ettikleri örnekler ile yaptıkları çalışmada; 292 adet bilinen 
ve 329 adet yeni miRNA identifiye etmişlerdir. Sekiz safkan attan aldıkları iskelet kasında, karaciğerde ve kolonda yüksek verimlilikte miRNA'ların 21838589 ile 11973300 arası değişen sayılarda kısa okuma sekanslarının sonucu ile elde edilen \% 100 yüksek kalitede cDNA kütüphanesini oluşturmuşlardır. Kim ve ark. (2014) tarafindan atlarda kas, kolon ve karaciğer dokularında bulunan miRNA' ların uzunlukları ve dağılımları belirlenmiş ve bu miRNA'ların yaklaşık \% 83' nün sekansları 20-24 nt aralığında yoğunlaştığ 1 bulunmuştur. Ayrica elde edilen miRNA'larda en sık rastlanan uzunluğun tüm dokularda 23 nt olduğu tespit edilmiştir [29].

\section{Atlarda miRNA'ların dokulara göre profili}

Organ veya dokular için miRNA'nın ekpresyon profili göz önüne alındığında organ spesifik miRNA'ların alt kümelerini keşfetmek klinik olarak hastalıklar açısından önemlidir. Atlarda, karaciğer, iskelet kası ve kalın bağırsak dâhil olmak üzere başlıca organlarda miRNA'ların karakterizasyonunun yapılması önemli at hastalıkları ile yakından ilişkilidir. Kim ve ark. (2014) tarafindan at dokularında bilinen miRNA'ları analiz edilmiş ve alt kümeler şeklinde dokuya özel miRNA'lar (kas dokusunda 36, kolon örneklerinde 99 ve karaciğerde 31) tespit edilmiştir. İkincil yapılarda, Dicer bölünme mevkilerinin ve bilinmeyen miRNA'ların minumum serbest enerjileri de belirlenmiştir. $\mathrm{Bu}$ analizler ile atlarda 329 adet bilinmeyen miRNA sekansı yeni aday miRNA olarak belirlenmiştir. Atlarda miRNA'lar dokuya özel bir biçimde eksprese edilip; kas örneklerinde 31 , kolon örneklerinde 123 ve karaciğer örneklerinde 45 yeni miRNA tespit edilmiştir. Kolona özgü miRNA'ların kolonun düzenleyici sisteminde daha karmaşık rolleri olduğu ortaya koyulmuştur [17,29].

\section{Atlarda miRNA'ların Kromozomal Dağılımı}

Atlarda toplam 292 bilinen miRNA, 29. ve 31. kromozomlar hariç diğer kromozomlar arasında haritalanmıştır [35]. Yaklaş1k 160 adet miRNA'nın 3 kb büyüklüğündeki bir bölgede bir arada lokalize olduğu tespit edilmiştir. At genomunda miRNA'lar1 kodlayan genler 51. farklı küme halinde bireysel kromozomlar üzerinde değişik bölgelerde lokalize olmuştur. Örneğin, 24. Kromozomda 4 miRNA kümesinde 40 miRNA geni bulunurken $6,12,14,16$, 18 ve 20 . kromozomlarda sadece 2 miRNA geni bulunmaktadir.

\section{At miRNA'larında Nükleotid Dağılım Eğilimleri}

miRNA'nın 5' uç dizilerinin karakterizasyonu önemlidir çünkü miRNA'nın çekirdek sekansı miRNA 'nın hedef mRNA'ya bağlanmasında kritiktir [1, 14]. Ökaryotlarda miRNA'ların nükleotid sekans analizi 5' pozisyonu açık bir şekilde "U" ve "A" için eğilimlidir [16]. Kim ve ark. (2014) at genomunda dokuya özel miRNA'ların 5' ucunda en s1k nükleotidin "U" olduğunu ve ardından A'in geldiğini ortaya koymuştur ve bu bulgular diğer organizmalar ile yapılan çalışmalardan elde edilen sonuçlar ile tutarlıdır [2]. Atlarda tüm doku miRNA'larının üçüncü ve altıncı pozisyonlarda " $\mathrm{C}+\mathrm{G}$ " yüzdelerinin yüksek olduğu belirlenmiştir. miRNA çekirdek dizisindeki 6. pozisyondaki " $\mathrm{C}+\mathrm{G}$ " içeriği miRNA için fonksiyon düzenleyici ve uyarıcı etkisi vardır. Kolondaki miRNA'lar farklı organlara göre bütün miRNA çekirdek nükleotidlerinde daha yüksek "C $+\mathrm{G}$ " oranına sahip olması kolonun fonksiyonlarındaki farklılıktan kaynaklanabilir [2]. Organspesifik miRNA'ların 5' ucundaki ilk nükleotidi kas, kolon ve karaciğer dokularında sırasıyla \% 40, $\% 35$ ve \% 43 siklıkla "U”dir. Aynı şekilde, atlarda 18-19 nükleotid uzunluktaki miRNA'lar az olmasına rağmen sadece kolonda 18 ve 19 nükleotid uzunluğundaki miRNA'ların 5' ucunda " $G$ " ve "A" bulunur. miRNA'ları oluşturan nükleotidler arasında "A+U" dağılımı, ortalama \% 72 olarak hesaplanmıştır. Ancak; tüm dokularda 3'ten 6'ya kadar olan nükleotid pozisyonunda " $\mathrm{C}+\mathrm{G}$ " oranı " $\mathrm{A}+\mathrm{U}$ " oranından daha fazladır. Ayrıca kolon miRNA'sında 2'den 8'e kadar olan miRNA çekirdeğine sahip olan nükleotid pozisyonlarında "C+G"nin, "A+U”e göre daha fazla olduğu belirlenmiştir [12,37].

\section{Atlarda Polisistronik miRNA'ların Kromozomal Lokalizasyonları}

miRNA'ların biyogenezi ya monosistronik (tek bir gene ait) ya polisistronik (birden fazla gene ait) lokusların transkripsiyonu ile başlatılır $[4,8,25]$. miRNAların yaklaşık yarısı küme yerleşimi gösterir [34]. Kümelenmiş miRNA' ların önemli bir özelliği de türler arasında korunmuş olması, homolog miRNA'ların tüm türlerde gözlenmesidir. Bu nedenle miRNA'ların kromozomlar üzerinde polisistronik dağılımı önemlidir [28].

Kim ve ark. (2014) ve Zhou ve ark. (2009) at genomunda kromozom 17 üzerinde miR-17-92 kü- 
mesini saptamıştır. Bu kümenin miR-17, miR-18a, miR-19a, miR-19b, miR-20a ve miR-92'yi barınd1ran ve insan dâhil tüm omurgalılarda iyi korunan bir küme olduğu bilinmektedir. Memelilerde miR-1792 kümesi iki miR-106b-25 ve miR-106a-363 adında paraloglara (bir tek genomda gen ikilenmesi ile oluşmuş ve işlevleri farklılaşmış) ayrılmıştır. Ayrıca 13. kromozom üzerinde lokolize olmuş eski küme ve $\mathrm{X}$ kromozomunda lokalize olmuş son kümeler tespit etmişlerdir.

Kim ve ark. (2014) bilinen miRNA'ların yaklaşık \% 53'ünün bir polisistronik birimin bir parçası olarak gözlendiğini ortaya koymuştur. İnsan verileri ile karşılaştırıldığında atta kromozomal konumda kısmi farkl11ık olsa da miRNA'ların kümelenme özelliğinin korunmuş olduğu ortaya çıkmıştır. Atlarda polisistronik birimlerdeki miRNA'ların oranı (\% 50) zebrabalıklarının miRNA'ları ile benzerdir ve miRNA kümelerinin yaklaşık \% 72'si hesaplama analizi ile tespit edilmiş at miRNA'ları ile aynıdır [41]. Ancak polisistron pozisyonlarda olduğu düşünülen 160 adet miRNA'ın 45'i in silico yapılan çalışmalarda ortolog pozisyonda tespit edilememiştir. Bunun nedeni olarak farklı miRNA kümelenmeleri gösterilmektedir. İn silico analizde BLAST tarafindan belirlenen limitli miRNA'lardan faydalanılırken bu çalışmada miRNA kümeleme, YNS teknolojisi dizi verilerine dayanarak yapılmıştır. Zhou ve ark. (2009) 2. kromozom üzerindeki miR-302a, $-302 b,-302 c,-302 d$ ve -367 ve X kromozom üzerindeki miR-1912 ve -1264'i, polisistronik miRNA'lar olarak bildirmiştir. Kim ve ark. (2014) tarafindan bulunan polisistronik miRNA'lar Zhou ve ark. (2009) tarafindan rapor edilmemiştir. Elde edilen bulgular at miRNA'ları için kümelenme özelliğinin ortaya çıkarılması için daha fazla çalışma yapılmasının gerekliliğini göstermektedir.

\section{Sonuç}

$\mathrm{Bu}$ bilgiler 1şığında at genomunda miRNA üzerine yapılan çalışma sayısının oldukça sınırlı olduğu belirlenmiştir. YNS teknolojisi kullanılması ile atta normal dokularda bilinen 292 ve yeni 329 miRNA tespit edilmiş ve önemli ölçüde at miRNA veritabanını zenginleştirdiği ve at miRNA'ları için değerli bir referans oluşturduğu ortaya çıkmıştır. Buna ek olarak, at dokularında genel miRNA ifade profili miRNA'ların birbirinden ayrı bir doku-spesifik bir şablonda ifade olduğu bulunmuştur. miRNA'nın sekansı, kromozomlar üzerindeki dağılımı ve kümelenme özellikleri atta miRNA' ların biyolojik işlevlerinin aydınlatılmasında önemlidir. miRNA'lar doku gelişimi ve spesifik dokuların işlevinde önemli bir rol oynamaktadır ve bu nedenle, çeşitli patofizyolojik durumlarda çok değerli bir biomarker olarak geliştirilebilir.

\section{Kaynaklar}

1. Ai J, Zhang R, Li Y, Pu J, Lu Y, Jiao J, Li K, Yu B, Li Z, Wang R, Wang L, Li Q, Wang N, Shan H, Li Z, Yang B, (2009). Circulating microRNA-1 as a potential novel biomarker for acute myocardial infarction. Biochem Biophys Res Commun. 391(1):73-7.

2. Ai L, Xu M, Chen M, Zhang Y, Chen S, (2012). Characterization of microRNAs in Taenia saginata of zoonotic significance by Solexa deep sequencing and bioinformatics analysis. Parasitol Res 110: 2373-2378.

3. Akkaya Z, Dinçer P, (2013). Tedavi yaklaşımlarında yeni bir dönem: Kodlamayan RNA'lar ve hastalıklar. Marmara Medical Journal; 26: 5-10

4. Ambros V, Bartel B, Bartel DP, Burge CB, Carrington JC, Chen X, (2003). A uniform system for microRNA annotation. RNA 9: 277-99.

5. Barrey E, Bonnamy B, Barrey E, Mata X, Chaffaux S, (2010). Muscular microRNA expressions in healthy and myopathic horses suffering from polysaccharide storage myopathy or recurrent exertional rhabdomyolysis. Equine Vet J 42: 303-310.

6. Birney E, Stamatoyannopoulos JA, Dutta A, (2007). Identification and analysis of functional elements in $1 \%$ of the human genome by the ENCODE pilot Project. Nature.447: 799-816.

7. Boggs RM, Wright ZM, Stickney MJ, Porter WW, Murphy KE, (2008). MicroRNA expression in canine mammary cancer. Mamm Genome 19: 561-569.

8. Borchert GW, Davidson BL, (2006). RNA polymerase III transcribes human microRNAs. Nat Struct Mol Biol 13:1097-101.

9. Buza T, Arick M, Wang H, Peterson DG, (2014). Computational prediction of disease microRNAs in domestic animals. BMC Research Notes 7: 403.

10. Carninci P, Kasukawa T, Katayama S, (2005). The transcriptional landscape of the mammalian genome. Science. 309:1559-63.

11. Carrington JC, Ambros V, (2003). Role of microRNAs in plant and animal development. Sci Signal 301: 336-338.

12. Creighton CJ, Reid JG, Gunaratne PH, (2009). Expression profiling of microRNAs by deep sequencing. Brief Bioinform 10: 490-497.

13. Curtis HJ, Sibley CR, Wood MJA, (2012). Mirtrons, an emerging class of atypical miRNA. Wiley Interdiscip Rev RNA 3: 617-32. 
14. Engels B, Hutvagner G, (2006). Principles and effects of microRNA-mediated post-transcriptional gene regulation. Oncogene 25: 6163-6169.

15. Fan P, Chen Z, Tian P, Liu W, Jiao Y, Xue Y, (2013). miRNA biogenesis enzyme drosha is required for vascular smooth muscle cell survival. PLoS ONE. 8: 1-11.

16. Frank F, Sonenberg N, Nagar B, (2010). Structural basis for 5'-nucleotide base-specific recognition of guide RNA by human AGO2. Nature 465: 818-822.

17. Galuppo L, Snyder J, Pascoe J, (1995). Laparoscopic anatomy of the equine abdomen. Am J Vet Res 56: 518-531.

18. Griffiths-Jones S, (2004). The microRNA Registry. Nucleic Acids Res., Database issue 32: D109-11.

19. Grishok A, Pasquinelli A E, Conte D, Li N, Parrish S, Ha I, (2001). Genes and Mechanisms Related to RNA Interference Regulate Expression of the Small Temporal RNAs that Control C. elegans Developmental Timing. Cell 106: 24-34.

20. Guo L, Lu Z, (2010). The Fate of miRNA* Strand through Evolutionary Analysis: Implication for Degradation As Merely Carrier Strand or Potential Regulatory Molecule. PLoS One. June 30; 5(6):e11387

21. Güzelgül F, Aksoy K, (2015). Bir Gen İfade Düzenleyicisi miRNA. Arşiv Kaynak Tarama Dergisi 24(4): 472-493.

22. Havens MA, Reich AA, Duelli DM, Hastings ML, (2012). Biogenesis of mammalian microRNAs by a non-canonical processing pathway. Nucleic Acids Res 40: 4626-40.

23. He L, Hannon GJ, (2004). MicroRNAs: small RNAs with a big role in gene regulation. Nat Rev Genet 5: 522-31.

24. Hentze MW, Preiss T, (2013). Circular RNAs splicing's enigma variations. EMBO J. 32: 923-5.

25. Jha A, Mehra M, Shankar R, (2011). The regulatory epicenter of miRNAs. J Biosci. 36: 621-8.

26. Kaikkonen MU, Lam MT, Glass CK, (2011). Non-coding RNAs as regulators of gene expression and epigenetics. Cardiovasc Res 90: 430-40.

27. Kim, YK, Kim VN, (2007). Processing of intronic microRNAs. EMBO J. 26: 775-783.

28. Kim, VN, Han J, Siomi MC, (2009). Biogenesis of small RNAs in animals. Nature Rev. Mol. Cell Biol 10:126-139

29. Kim MC, Lee SW, Ryu DY, Cui FJ, Bhak J, Kim Y, (2014). Identification and Characterization of MicroRNAs in Normal Equine Tissues by Next Generation Sequencing. PLoS ONE 9(4): e93662.

30. Ladewig E, Okamura K, Flynt AS, Westholm JO, Lai EC, (2012). Discovery of hundreds of mirtrons in mouse and human small RNA data. Genome Res. 22: 1634-45.
31. Lau NC, Lim LP, Weinstein EG, Bartel DP, (2001). An Abundant Class of Tiny RNAs with Probable Regulatory Roles in Caenorhabditis elegans. Science 294:858-62.

32. Lee RC, Feinbaum RL, Ambros V, (1993). The C. elegans heterochronic gene lin-4 encodes small RNAs with antisense complementarity to lin-14. Cell. 75: 843-54.

33. Lee RC, Ambros V, (2001). An Extensive Class of Small RNAs in Caenorhabditis elegans. Science 294: 862-64.

34. Lee Y, Kim M, Han J., Yeom KH., Lee S. And Baek SH. et al, (2004). MicroRNA genes are transcribed by RNA polymerase II. EMBO J. 23:4051-60.

35. Liang Y, Ridzon D, Wong L, Chen C, (2007). Characterization of microRNA expression profiles in normal human tissues. BMC Genomics 8: 166.

36. Lund E., Güttinger S., Calado A., Dahlberg JE., Kutay U, (2004). Nuclear Export of MicroRNA Precursors. Science 303:95-8.

37. Olena AF, Patton JG, (2010). Genomic organization of microRNAs. J Cell Physiol. Mar;222(3):540-5.

38. O'toole AS, Miller S, Haines N, Zink MC, Serra MJ, (2006). Comprehensive thermodynamic analysis of 3' doublenucleotide overhangs neighboring Watson-Crick terminal base pairs. Nucleic Acids Res. 34: 3338-3344.

39. Pauli A, Rinn JL, Schier AF, (2011).Non-coding RNAs as regulators of embryogenesis. Nat Rev Genet 12: 136-49.

40. Ruvkun G, (2001). Molecular biology. Glimpses of a tiny RNA world. Science 294: 797-799.

41. Thatcher EJ, Bond J, Paydar I, Patton JG, (2008). Genomic organization of zebrafish microRNAs. BMC Genomics 9: 253.

42. Treiber T, Treiber N, Meister G, (2012). Regulation of microRNA biogenesis and function. Tromb Haemotology 107:605-10.

43. Westholm JO, Lai EC, (2011). Mirtrons: microRNA biogenesis via splicing. Biochimie 93: 1897-904.

44. Zhou M, Wang Q, Sun J, Li X, Xu L, (2009). In silico detection and characteristics of novel microRNA genes in the Equus caballus genome using an integrated $\mathrm{ab}$ initio and comparative genomic approach. Genomics 94: 125-131.

45. Zhou M, Wang Q, Sun J, Li X, Xu L, Yang H, Shi H, Ning S, Chen L, Li Y, He T, Zheng Y, (2013). MicroRNA-mediated gene regulation: potential applications for plant genetic engineering. Plant Mol Biol. 83(1-2):59-75. 